\title{
Structural characterization of diabolic acid-based tetraester, tetraether and mixed ether/ester, membrane-spanning lipids of bacteria from the order Thermotogales
}

\author{
Jaap S. Sinninghe Damsté • W. Irene C. Rijpstra • \\ Ellen C. Hopmans $\cdot$ Stefan Schouten • Melike Balk • \\ Alfons J. M. Stams
}

Received: 22 December 2006 / Revised: 25 June 2007 / Accepted: 2 July 2007 / Published online: 21 July 2007

(C) Springer-Verlag 2007

\begin{abstract}
The distribution of core lipids in the membranes of nine different species of the order Thermotogales, one of the early and deep branching lineages in the Bacteria, were examined by HPLC/MS and demonstrated to consist of membrane-spanning diglycerol lipids comprised of diabolic acid-derived alkyl moieties. In the Thermotoga species the core membrane lipids are characterized by the presence of both ester and ether bonds, whereas in the phylogenetically more distinct Thermosipho and Fervidobacterium spp. only ester bonds occur. A tentative biosynthetic route for the biosynthesis of these membrane-spanning lipids is proposed. Since species of the order Thermotogales are assumed to have occurred early during the evolution of life on Earth, as suggested by its position in the phylogenetic tree of life, these data suggest that the ability to produce both ether and ester glycerol membrane lipids developed relatively early during microbial evolution.
\end{abstract}

Keywords Diabolic acid · Ether lipids · Ester lipids · Thermotoga $\cdot$ Thermosipho $\cdot$ Fervidobacterium

Communicated by Friedrich Widdel.

J. S. S. Damsté $(\bowtie)$ · W. I. C. Rijpstra · E. C. Hopmans • S. Schouten

Department of Marine Biogeochemistry and Toxicology, Royal Netherlands Institute for Sea Research (NIOZ), PO Box 59, 1790 AB Den Burg, Texel, The Netherlands e-mail: damste@nioz.nl

M. Balk · A. J. M. Stams

Laboratory of Microbiology, Wageningen University, Wageningen, The Netherlands

\begin{abstract}
Abbreviations
APCI Atmospheric pressure chemical ionization BSTFA $N, O$-bis(trimethylsilyl)trifluoroacetamide DCM Dichloromethane GDGT Glycerol dialkyl glycerol tetraethers TLF Total lipid fraction
\end{abstract}

\section{Introduction}

The group of anaerobic bacteria falling in the order Thermotogales represents a very deep phylogenetic branch within the phylogenetic tree of life based upon the ribosomal RNA gene (Woese 1987). Within this order, members of the genus Thermotoga have an upper growth limit of $90^{\circ} \mathrm{C}$ and represent, together with species in the order Aquificales, cultivated bacteria with the highest known growth temperatures. Bacteria belonging to the Thermotogales occur widespread in the environment: they thrive within continental solfatara springs of low salinity, shallow and deep-sea marine hydrothermal systems and high-temperature marine and continental oil fields (see Huber and Hannig 2005 for a recent review). Their strict organotrophic way of life makes them consumers of microbial organic matter within high temperature ecosystems. Within the order Thermotogales, the genera Thermotoga, Thermosipho, Fervidobacterium, Geotoga, Petrotoga and Marinitoga have been described, all belonging to the single family Thermotogaceae (Huber and Hannig 2005). The type species T. maritima for the genus Thermotoga, also the first identified member of the Thermotogales, was isolated from a geothermally heated, shallow marine sediment in Italy (Huber et al. 1986). Subsequently, quite a number of phylogenetically closely related (T. neapolitana, T. petrophila, T. naphtophila) and slightly more distant (T. thermarum, T. elfii, T. subterranea, 
T. hypogea, T. lettingae) species were isolated, mostly from marine settings. Thermotoga-related organisms have been detected in oil reservoirs (Huber and Hannig 2005), whilst members of the genus Fervidobacterium seem to be restricted to hydrothermal settings with low salinity such as hot springs. For example, Fervidobacterium pennivorans was firstly isolated from a hot spring on San Miguel (the Azores) (Friedrich and Antranikian 1996). Members of the genus Thermosipho have been isolated from a wide variety of high temperature environments such as marine hydrothermal springs (e.g. T. africanus) and deep sea hydrothermal vents (e.g. T. melanesiensis) (Antoine et al. 1997; Huber et al. 1989).

To be able to grow at high temperatures, the members of the Thermotogales possess a variety of thermostable enzymes and proteins, which are also of biotechnological interest. In addition, the cell membranes of these organisms must be able to cope with high temperatures. Indeed, a variety of unusual membrane lipids has been reported for members of the Thermotogales. Unusual, long-chain dicarboxylic (diabolic) acids are present in the core lipids of the genus Thermotoga (Jeanthon et al. 1995; Manca et al. 1992; Windberger et al. 1989; Carballeira et al. 1997; DeRosa et al. 1988; Huber et al. 1986). About 50\% of the total polar lipids of T. maritima are two amphipathic monopolar glycolipids with a very rare $\alpha-(1-4)$ diglucosyl structure (Manca et al. 1992).

In the present paper, we describe in detail the structures of these and other lipids in a suite of bacteria belonging to the Thermotogales and discuss their distributions. We applied an HPLC/MS method, which for the first time enabled to characterize the full membrane-spanning core lipids.

\section{Materials and methods}

Cultures

Cells were grown in 500-ml batch cultures in 1.2-1-bottles at temperatures of $55-80^{\circ} \mathrm{C}$ and with either medium A or B (see Table 1). Medium A was composed (per liter demineralized water) of $\mathrm{KCl} \quad 0.335 \mathrm{~g} ; \mathrm{MgCl}_{2} \cdot 6 \mathrm{H}_{2} \mathrm{O} \quad 4.0 \mathrm{~g}$; $\mathrm{MgSO}_{4} \cdot 7 \mathrm{H}_{2} \mathrm{O} 3.45 \mathrm{~g} ; \mathrm{NH}_{4} \mathrm{Cl} 0.25 \mathrm{~g} ; \mathrm{K}_{2} \mathrm{HPO}_{4} 0.14 \mathrm{~g} ; \mathrm{NaCl}$ $10.0 \mathrm{~g}$; glucose $3.8 \mathrm{~g}$; yeast extract $0.5 \mathrm{~g}$; peptone $0.5 \mathrm{~g}$; $\mathrm{NaHCO}_{3}, 2.0 \mathrm{~g} ; \mathrm{Na}_{2} \mathrm{~S} .7-9 \mathrm{H}_{2} \mathrm{O}, 0.40 \mathrm{~g}$; trace element solution, $10 \mathrm{ml}$ and vitamin solution, $10 \mathrm{ml}$, which were based on medium 141 of DSM (http://www.dsmz.de); $\mathrm{CaCl}_{2} \cdot 2 \mathrm{H}_{2} \mathrm{O}, 0.140 \mathrm{~g}$; resazurin, $0.5 \mathrm{mg}$. The medium was anaerobically dispensed into serum bottles and a gas phase of $180 \mathrm{kPa} \mathrm{N} \mathrm{N}_{2} / \mathrm{CO}_{2}(80 / 20 \mathrm{v} / \mathrm{v})$ was applied. $\mathrm{NaHCO}_{3}$, $\mathrm{Na}_{2} \mathrm{~S} .7-9 \mathrm{H}_{2} \mathrm{O}$, glucose, $\mathrm{CaCl}_{2} \cdot 2 \mathrm{H}_{2} \mathrm{O}$ and vitamin solution were added after sterilization. The $\mathrm{pH}$ was 7.0-7.2. Medium B is a modified DSM medium 640 and composed (per liter demineralized water) of $\mathrm{NH}_{4} \mathrm{Cl} 0.90 \mathrm{~g} ; \mathrm{NaCl}$ $0.90 \mathrm{~g} ; \mathrm{MgCl}_{2} \cdot 6 \mathrm{H}_{2} \mathrm{O} 0.40 \mathrm{~g} ; \mathrm{KH}_{2} \mathrm{PO}_{4} 0.75 \mathrm{~g} ; \mathrm{K}_{2} \mathrm{HPO}_{4}$ $1.50 \mathrm{~g}$; peptone $0.50 \mathrm{~g}$; yeast extract $0.50 \mathrm{~g}$; trace element solution SL-10 (see DSM medium 320), $1.00 \mathrm{ml}$; $\mathrm{FeCl}_{3} \cdot 6 \mathrm{H}_{2} \mathrm{O} 2.50 \mathrm{mg}$; glucose $3.8 \mathrm{~g}$; cysteine- $\mathrm{HCl} \cdot \mathrm{H}_{2} \mathrm{O}$, $0.75 \mathrm{~g}$; resazurin $0.5 \mathrm{mg}$. The medium was anaerobically dispensed into serum bottles and a gas phase of $180 \mathrm{kPa} \mathrm{N}$ $(100 \%)$ was applied. Glucose and cysteine- $\mathrm{HCl} \cdot \mathrm{H}_{2} \mathrm{O}$ were added after sterilization. The $\mathrm{pH}$ was adjusted to $\mathrm{pH}$ 7.2. The cultures were inoculated with cells from the DSM collection of microorganisms (see Table 1 for strain number) and were harvested in their exponential growth phase. Two different batches of $T$. lettingae were grown and analysed separately.

Table 1 Bacteria from the order Thermotogales with some background information and the culture conditions used in this study

\begin{tabular}{|c|c|c|c|c|c|c|}
\hline \multirow[t]{2}{*}{ Bacterial species } & \multirow[t]{2}{*}{ Source for the isolate } & \multirow{2}{*}{$\begin{array}{l}\text { Optimal growth } \\
\text { temperature }\left({ }^{\circ} \mathrm{C}\right)\end{array}$} & \multirow[t]{2}{*}{ Reference } & \multirow{2}{*}{$\begin{array}{l}\text { DSM strain } \\
\text { number }\end{array}$} & \multicolumn{2}{|c|}{ Culture conditions } \\
\hline & & & & & Medium $^{\mathrm{a}}$ & $\mathrm{T}\left({ }^{\circ} \mathrm{C}\right)$ \\
\hline Thermotoga maritima & Anaerobic marine sediment, Italy & 80 & Huber et al. (1986) & 3109 & A & 80,55 \\
\hline T. neapolitana & Submarine hot spring, Italy & 85 & Jannasch et al. (1988) & 4359 & A & 80 \\
\hline T. elfii & Oil-producing well, Africa & 65 & Ravot et al. (1995) & 9442 & A & 65 \\
\hline T. lettingae & $\begin{array}{l}\text { Sulfate-reducing bioreactor, } \\
\text { The Netherlands }\end{array}$ & 65 & Balk et al. (2002) & 14385 & A & 65 \\
\hline T. hypogea & Oil-producing well, Africa & 70 & Fardeau et al. (1997) & 11164 & $\mathrm{~B}$ & 70 \\
\hline Thermosipho sp. & Spring, New Zealand & 65 & & 6568 & $\mathrm{~B}$ & 65 \\
\hline T. africanus & $\begin{array}{l}\text { Marine hydrothermal spring, } \\
\text { Obock }\end{array}$ & 75 & Huber et al. (1989) & 5309 & $\mathrm{~B}$ & 75 \\
\hline T. melanesiensis & $\begin{array}{l}\text { Deep sea hydrothermal vent, } \\
\text { Pacific Ocean }\end{array}$ & 70 & Antoine et al. (1997) & 12029 & B & 70 \\
\hline Fervidobacterium pennivorans & Hot mud of spa, Italy & 65 & Koch et al. (1997) & 9078 & $\mathrm{~B}$ & 65 \\
\hline
\end{tabular}

a See Materials and method sections for a description of the media used 
Lipid analysis

Lyophilized cells were repeatedly $(\times 5)$ ultrasonically extracted with dichloromethane (DCM)/ methanol (MeOH) $(2: 1 \mathrm{v} / \mathrm{v})$. The solvent of the combined extracts was removed by rotary evaporation at reduced pressure. The extract was taken up in DCM and weighed in a small vial by removing the solvent under a gentle stream of nitrogen. An aliquot (ca. $1 \mathrm{mg}$ ) of the extract to which a known amount of the internal standard, 2-methylheneicosane, was added, was methylated with $\mathrm{BF}_{3} / \mathrm{MeOH}$, filtered over a small pipette filled with silica using ethyl acetate as the eluent, and subsequently silylated with N,O-bis(trimethylsilyl)trifluoroacetamide (BSTFA) in pyridine at $60^{\circ} \mathrm{C}$ for $15 \mathrm{~min}$. These so-called total lipid fractions (TLF-1) were analysed with gas chromatography (GC) and gas chromatography-mass spectrometry (GC-MS). In selected cases, acetylation instead of silylation of the eluate obtained after chromatography over silica was performed following a procedure described elsewhere (Cox et al. 1972).

The cell residue after solvent extraction was, after addition of a known amount of the internal standard, 2-methylheneicosane, hydrolysed with $1 \mathrm{~N} \mathrm{KOH} / \mathrm{MeOH}(96 \%)$ by refluxing for $1 \mathrm{~h}$. The hydrolysate was neutralized with $2 \mathrm{~N}$ $\mathrm{HCl} / \mathrm{MeOH}$ and after addition of water extracted with DCM. This fraction was methylated, chromatographed over silica and silylated as described above and the resulting TLF-2 fraction was analyzed by GC and GC-MS. In specific cases alkaline hydrolysis was also performed with an aliquot of the solvent extract following the same procedure as described above. This resulted in a fraction named TLF1-OH which was also analyzed by GC and GC-MS.

For analysis of core lipids by high performance liquid chromatography/atmospheric pressure chemical ionization mass spectrometry (HPLC/APCI-MS) aliquots of the solvent extracts (ca. $2 \mathrm{mg}$ ) were separated over a small $\mathrm{Al}_{2} \mathrm{O}_{3}$ column using hexane/DCM $(1: 1 \mathrm{v} / \mathrm{v})$ and $\mathrm{DCM} / \mathrm{MeOH}$ as eluent to obtain apolar and polar fractions, respectively. The polar fraction was dissolved in hexane/propanol (99:1 $\mathrm{v} / \mathrm{v})$, filtered over an $0.4 \mu \mathrm{m}$ PTFE filter, and analysed by HPLC/APCI-MS.

\section{GC and GC-MS}

GC was performed using a Fisons GC8000 instrument, equipped with an on-column injector and a flame ionization detector. A fused silica capillary column $(25 \mathrm{~m} \times$ $0.32 \mathrm{~mm}$ ) coated with CP Sil-5 ( $\left.d_{f} 0.12 \mathrm{um}\right)$ was used with helium as carrier gas. The samples were injected at $70^{\circ} \mathrm{C}$ and the oven temperature was programmed to $130^{\circ} \mathrm{C}$ at $20^{\circ} \mathrm{C} / \mathrm{min}$ and then at $4^{\circ} \mathrm{C} / \mathrm{min}$ to $320^{\circ} \mathrm{C}$, at which it was held for $10 \mathrm{~min}$. GC-MS was performed on a HP 5890 gas chromatograph interfaced with a VG Autospec Ultima mass spectrometer operated at $70 \mathrm{eV}$ with a mass range of $\mathrm{m} / \mathrm{z} 40-800$ and a cycle time of $1.7 \mathrm{~s}$ (resolution 1,000). The gas chromatograph was equipped with a fused silica capillary column as described for GC. The carrier gas was helium. The same temperature program as for GC was used.

\section{HPLC/APCI-MS}

Membrane-spanning core lipids were analysed by HPLC/ APCI-MS according to Hopmans et al. (2000) with minor modifications. Analyses were performed on an Agilent 1100 series HPLC/MS instrument, equipped with an autoinjector and HP Chemstation software. Separation was achieved on an Alltech Prevail Cyano column $(150 \mathrm{~mm} \times$ $2.1 \mathrm{~mm} ; 3 \mu \mathrm{m})$. Flow rate of the hexane:propanol 99:1 (v/v) eluent was $0.2 \mathrm{ml} \mathrm{min}^{-1}$, isocratically for the first $5 \mathrm{~min}$, thereafter with a linear gradient to $1.8 \%$ propanol in $45 \mathrm{~min}$, subsequently to $10 \%$ propanol in $20 \mathrm{~min}$, and subsequently isocratically for the last $20 \mathrm{~min}$. Injection volume of the samples was usually $10 \mu \mathrm{l}$.

\section{Results}

Nine species of bacteria belonging to the order Thermotogales were analysed for their lipid composition; five of them are Thermotoga species (T. maritima, T. lettingae, T. elfi, T. neapolitana, T. hypogea), three are Thermosipho species (T. africanus, T. melanesiensis, T. sp.) and one is a Fervidobacterium species (F. pennivorans) (Table 1).

\section{Composition of total lipid fractions}

Figure 1a shows a typical gas chromatogram of a total lipid fraction (TLF-1) for T. maritima. In addition to straightchain fatty acids (predominantly $n-\mathrm{C}_{16}$ and $n-\mathrm{C}_{14}$ ), a number of more unusual lipids were detected. The first group comprises long-chain dicarboxylic acids; 15,16-dimethyltriacontanedioic acid (or diabolic acid 1; see Fig. 2 for structures) and 13,14-dimethyloctacosanedioic acid (2), identified on basis of mass spectral data reported previously (Carballeira et al. 1997; Klein et al. 1979). The mass spectra of $\mathbf{1}$ and $\mathbf{2}$ as methyl ester derivatives are shown in Fig. 3. The relative abundance of the $\mathrm{C}_{30}$ and $\mathrm{C}_{32}$ diabolic acids varied substantially between different species (Table 2). F. pennivorans also contained small amounts of a tentatively identified $\mathrm{C}_{34}$ diabolic acid. In some species, isomers of these diabolic acids, with virtually an identical mass spectrum but with a different retention time, were present in varying quantities. These probably represent stereoisomers, possibly related to the presence of two chiral centres in the middle of the carbon chain of the diabolic 

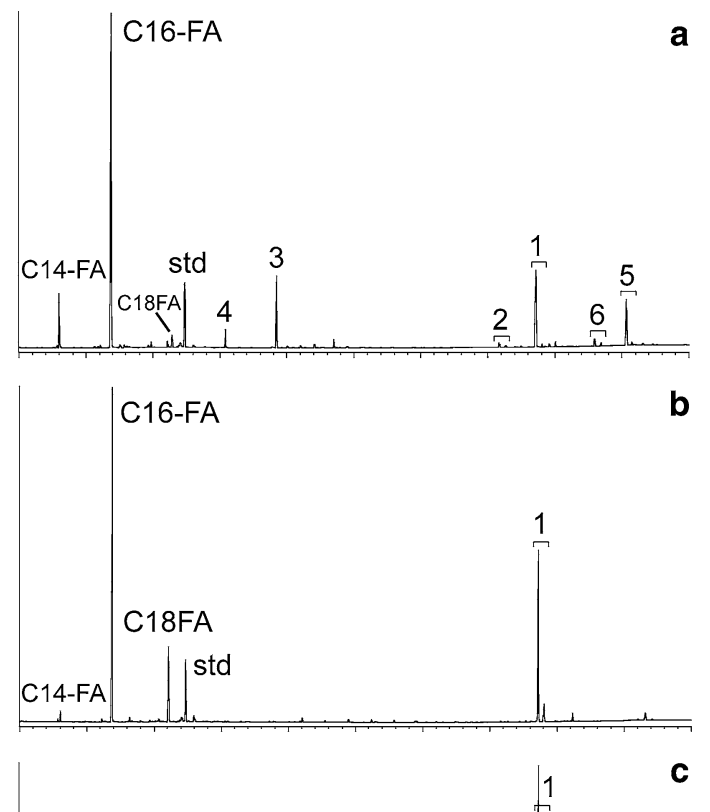

\section{$c$}
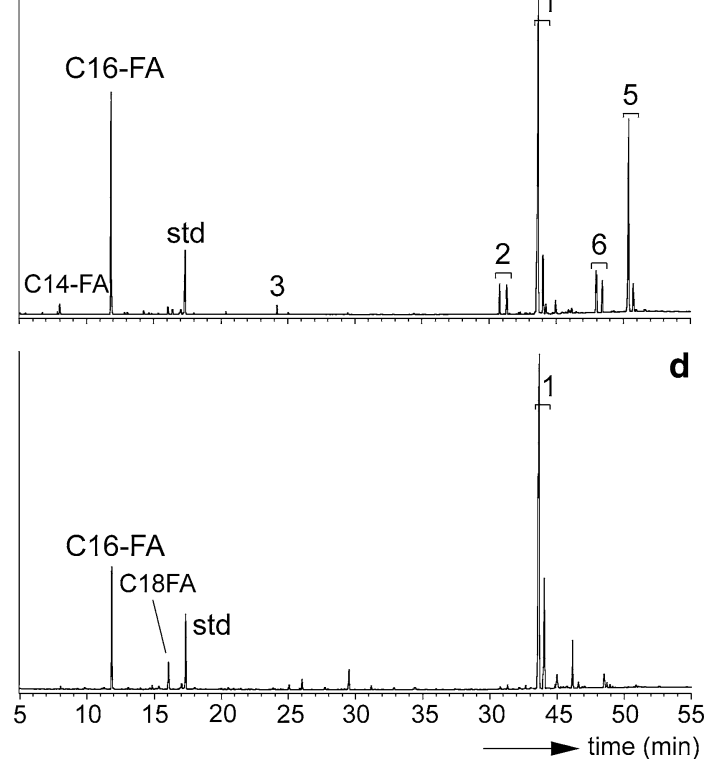

Fig. 1 Gas chromatograms of the total lipid fractions (TLF-1) (a-b) and these fractions after alkaline hydrolysis of the residue after extraction (TLF-2) (c-d) of Thermotoga maritima (grown at $55^{\circ} \mathrm{C}$ ) and $F$. pennivorans pennivorans, respectively. Fatty acids and alcohols were derivatized to the corresponding methyl esters and trimethylsilyl ethers prior to gas chromatographic analysis. Numbers refer to structures indicated in Fig. 2. FA Fatty acid, std internal standard

acids. The second group of unusual components comprises glycerol monoethers. 1-O-hexadecyl glycerol $(3)$ and 1-Otetradecyl glycerol (4) were identified by mass spectral data $(\mathrm{m} / \mathrm{z} 205$ base peak and appropriate molecular ion) and a co-elution experiment with an authentic standard. The higher molecular weight monoethers are 15,16-dimethyl30-glyceryloxytriacontanoic acid (5) and 13,14-dimethyl28-glyceryloxyoctadecanoic acid (6). Glycerol monoether 5 has been identified previously and the mass spectrum of $\mathbf{5}$ as acetyl derivative was reported (DeRosa et al. 1988). For

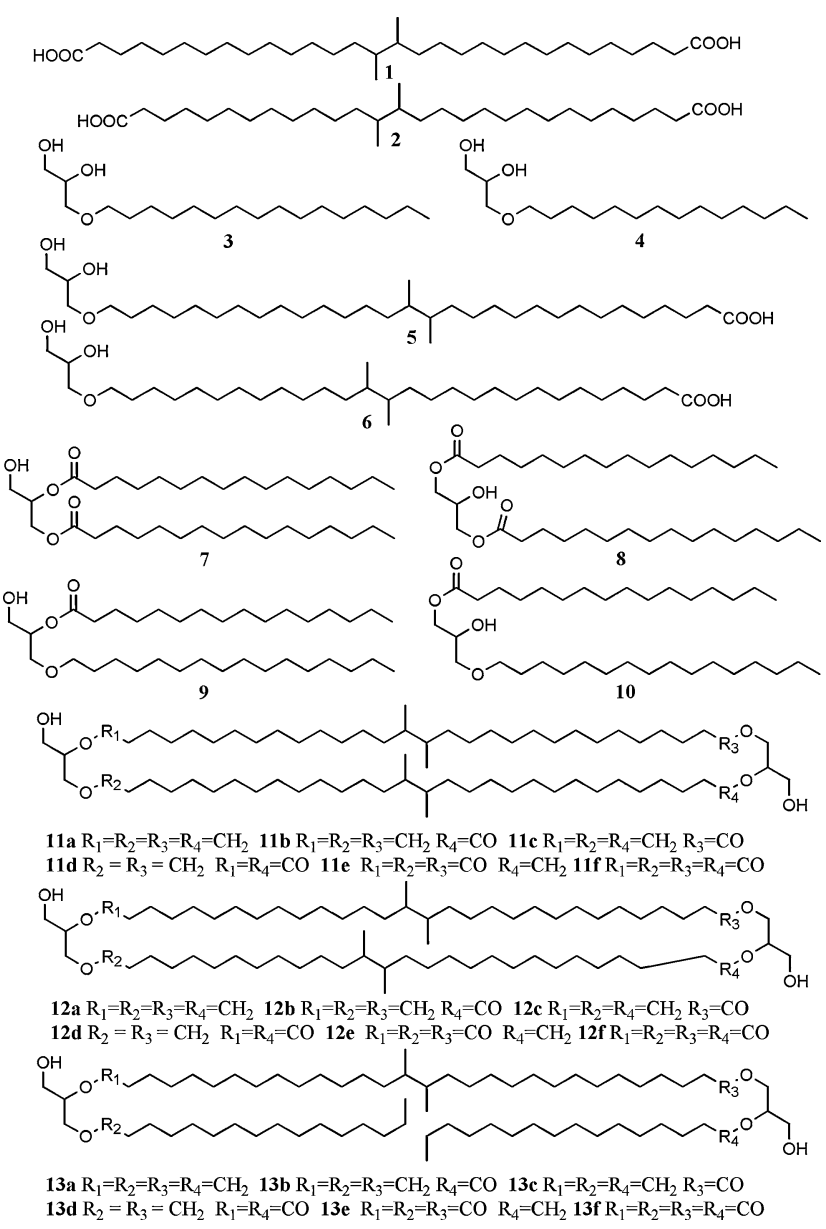

Fig. 2 Structures of lipids encountered in species from the order Thermotogales

identification purposes we used acetylation in addition to silylation to be able to compare the mass spectrum of the derivative of $\mathbf{5}$ with that reported in the literature (DeRosa et al. 1988). The mass spectrum of $\mathbf{5}$ as TMS derivative is shown in Fig. 3. Component $\mathbf{6}$ was tentatively identified by interpretation of its mass spectrum in comparison with that of 5 (Fig. 3). The relative amounts of monoethers 5 and $\mathbf{6}$ in the TLF- 1 vary widely between the examined species of the Thermotogales (Table 2). As observed for the diabolic acids $\mathbf{1}$ and 2, two additional minor isomers with similar mass spectrometric characteristics but different retention times are observed. The third group of lipids are glycerol dialkyl diesters and glycerol mixed ester/ethers. They were predominantly found in the TLF-1 of T. lettingae (Fig. 4a) and are composed of 1,2- and 1,3-diacyl glycerols (e.g. 7 and 8) and 1-alkyl, 2-acyl (e.g. 9) and 1-alkyl, 3-acyl (e.g. 10) glycerols. They were identified by comparison with mass spectra reported in the literature (Wood et al. 1980). Some Thermotoga species contained small amounts of 1,2di- $O$-alkyl glycerols.

The TLF after alkaline hydrolysis of the cell residue after extraction (TLF-2) contained a similar suite of lipids 

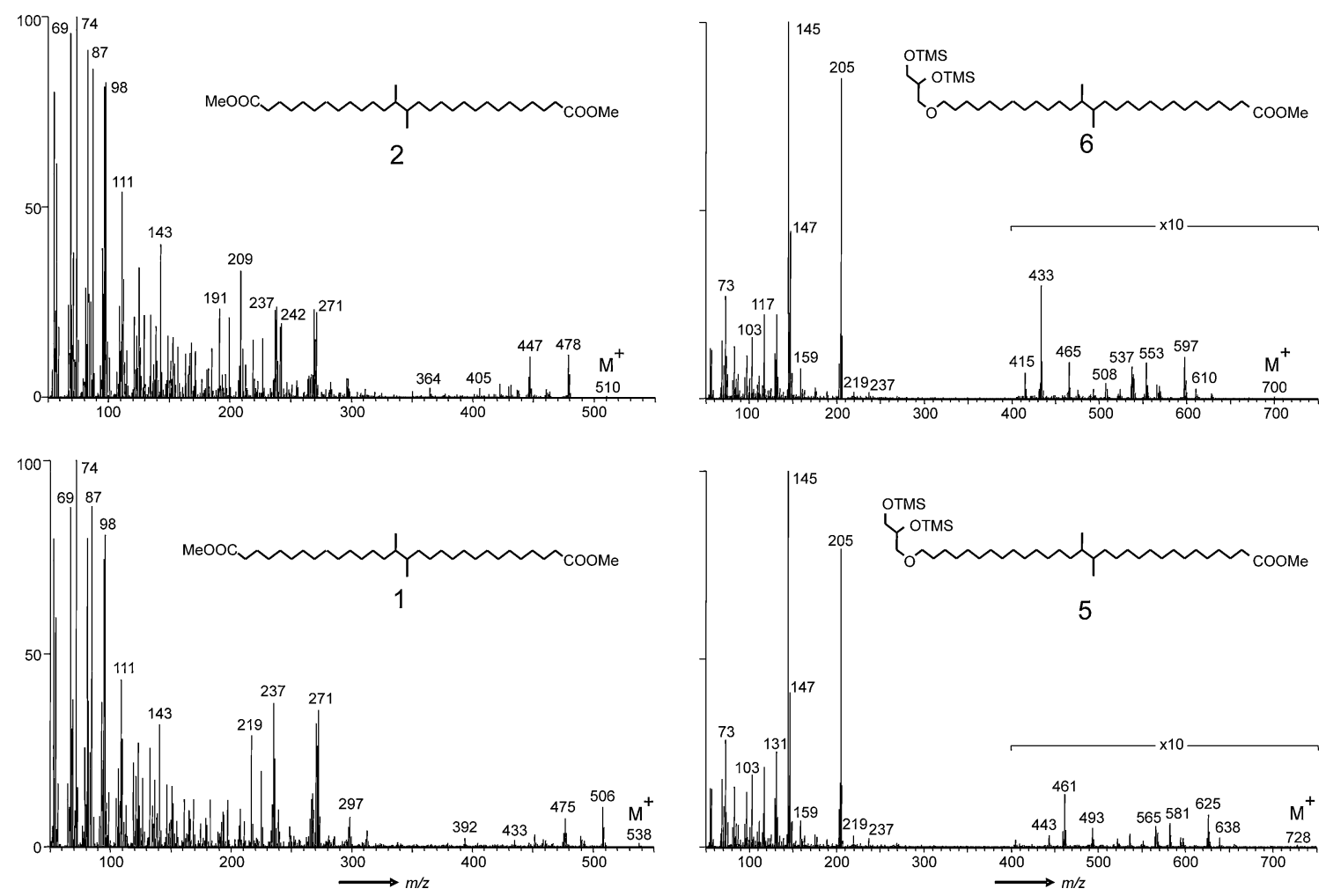

Fig. 3 Mass spectra (subtracted for background) of derivatised diabolic acids and diabolic acid glycerol ethers

as the TLF-1 (Table 2), albeit that some other components (e.g. unsaturated $\mathrm{C}_{16: 1}$ and $\mathrm{C}_{18: 1}$ fatty acids) were also present but only in the examined Thermosipho species. Most striking was that the characteristic long-chain diacids $\mathbf{1}$ and $\mathbf{2}$ and the complex monoethers $\mathbf{5}$ and $\mathbf{6}$ were relatively much more abundant in TLF-2 (Figs. 1c,d and 4b; Table 2), suggesting that they are predominantly formed by alkaline hydrolysis from larger lipid structures. A similar distribution was observed when the extract of $T$. lettingae (2nd batch) was subjected to alkaline hydrolysis (TLF-1-OH): the long-chain diacids $\mathbf{1}$ and $\mathbf{2}$ and the monoethers $\mathbf{5}$ and $\mathbf{6}$, which were not observed in the TLF-1 (Fig. 4a), are one of the most abundant lipids in the TLF-1-OH fraction (Fig. 4b). This indicates that these lipids are building blocks of larger, more complex lipids not amenable to GC.

The absolute amount of the most abundant lipids (in $\mathrm{mg} \mathrm{g}^{-1}$ dry weight) was for a number of species measured in both the TLF-1 and TLF-2 (Table 3). This showed that the amounts released by alkaline hydrolysis from the residue after extraction are still substantial. It also showed that the highest concentrations occur in the Thermotoga species and in $F$. pennivorans, while concentrations in the Thermosipho species are substantially lower. Quantification of the lipids in the TLF-1-OH fraction of T. lettingae (2nd batch) showed that the concentration increases substantially after alkaline hydrolysis of the extract.
Distribution of membrane-spanning core lipids in T. maritima

To characterize the membrane-spanning core lipids of the species belonging to the Thermotogales, the polar fraction of the solvent extract was analysed by an HPLC/APCI-MS method (Hopmans et al. 2000) slightly adjusted to enable the elution of more polar components than glycerol dialkyl glycerol tetraethers (GDGTs) from the LC column (see Materials and methods for details). Analysis of the polar lipids of Thermotoga maritima revealed a complex composition exemplified by the base peak chromatogram (Fig. 5a). The first eluting, small peak with a retention time of 29.0 min (labelled 11a in Fig. 5b) showed an APCI mass spectrum (Fig. 6a) characterised by peaks at $[\mathrm{M}+\mathrm{H}]^{+}$, $[\mathrm{M}+\mathrm{H}]^{+}-18$ (loss of water) and $[\mathrm{M}+\mathrm{H}]^{+}-74$ (loss of glycerol). This characteristic pattern is well known from archaeal GDGTs (Hopmans et al. 2000) and non-isoprenoidal GDGTs (Sinninghe Damsté et al. 2000), suggesting a tetraether structure. Indeed, upon alkaline hydrolysis of this fraction and re-analysis by HPLC/APCI-MS, this minor peak was now the most abundant peak in the base peak chromatogram. These data indicate a GDGT structure for the major peak comprised of two glycerol units connected by two $\mathrm{C}_{32}$ alkyl chains, resulting in a molecular mass of $1077\left(\mathrm{C}_{70} \mathrm{H}_{140} \mathrm{O}_{6}\right)$. Since 15,16-dimethyltriacontanedioic 
Table 2 Relative distribution (in \% of total quantified) of lipids in different species of the order Thermotogales
${ }^{a} T L F-1$ Total lipid fraction, $T L F-2$ total lipid fraction obtained after alkaline hydrolysis of the residue after extraction;

$T L F-O H$ Total lipid fraction after alkaline hydrolysis of the extract

${ }^{\mathrm{b}}$ Numbers refer to Fig. 2. Blank entries indicate that the lipid was not detected

\begin{tabular}{|c|c|c|c|c|c|c|c|c|c|c|}
\hline \multirow[t]{2}{*}{ Bacterial species } & \multirow[t]{2}{*}{ Fraction $^{\mathrm{a}}$} & \multicolumn{9}{|l|}{ Lipids $^{b}$} \\
\hline & & $\mathrm{C}_{14: 0} \mathrm{FA}$ & $\mathrm{C}_{16: 0} \mathrm{FA}$ & $\mathrm{C}_{18: 0} \mathrm{FA}$ & 1 & 2 & 3 & 4 & 5 & 6 \\
\hline \multirow{2}{*}{$\begin{array}{l}\text { Thermotoga } \\
\quad \text { maritima }\left(80^{\circ} \mathrm{C}\right)\end{array}$} & TLF-1 & 4.2 & 44.2 & 1.1 & 21.3 & 1.7 & 9.1 & 5.1 & 10.6 & 2.7 \\
\hline & TLF-2 & 1.7 & 25.9 & 0.9 & 38.7 & 4.2 & 2.2 & 1.0 & 17.6 & 7.8 \\
\hline \multirow[t]{2}{*}{ T. maritima $\left(55^{\circ} \mathrm{C}\right)$} & TLF-1 & 7.5 & 54.7 & 0.5 & 14.3 & 2.3 & 11.1 & 2.5 & 6.6 & 1.2 \\
\hline & TLF-2 & 0.7 & 15.0 & 0.4 & 48.4 & 4.6 & 0.7 & 0.2 & 23.8 & 6.2 \\
\hline \multirow[t]{2}{*}{ T. neapolitana } & TLF-1 & 4.6 & 61.3 & 2.8 & 17.3 & 1.3 & 3.7 & 0.7 & 7.1 & 1.2 \\
\hline & TLF-2 & 1.9 & 46.5 & 2.8 & 26.4 & 2.1 & 0.6 & & 15.8 & 3.9 \\
\hline \multirow[t]{2}{*}{ T. elfii } & TLF-1 & 3.5 & 61.0 & 4.0 & 28.2 & 2.6 & 0.5 & 0.1 & 0.2 & \\
\hline & TLF-2 & 1.2 & 20.0 & 1.2 & 70.7 & 6.4 & 0.2 & & 0.3 & \\
\hline \multirow[t]{2}{*}{ T. lettingae (1st batch) } & TLF-1 & 3.0 & 37.2 & 5.9 & 24.6 & 5.2 & 6.9 & 3.9 & 8.3 & 5.0 \\
\hline & TLF-2 & 0.8 & 11.6 & 1.0 & 48.3 & 7.8 & 2.2 & 0.9 & 18.7 & 8.7 \\
\hline \multirow[t]{2}{*}{ T. lettingae (2nd batch) } & TLF-1-OH & 6.3 & 26.4 & 1.1 & 32.6 & 8.8 & 4.8 & 5.8 & 8.5 & 5.6 \\
\hline & TLF-2 & 0.5 & 7.4 & 0.3 & 57.6 & 14.1 & 0.4 & 0.2 & 11.8 & 7.7 \\
\hline \multirow[t]{2}{*}{ T. hypogea } & TLF-1 & 4.8 & 54.5 & 2.3 & 14.1 & 2.3 & 7.4 & 3.5 & 8.1 & 3.0 \\
\hline & TLF-2 & 0.5 & 4.5 & 1.0 & 47.4 & 1.5 & 0.6 & 0.1 & 33.3 & 11.1 \\
\hline \multirow[t]{2}{*}{ Thermosipho sp. } & TLF-1 & 7.9 & 51.5 & 28.0 & 12.6 & & & & & \\
\hline & TLF-2 & 2.6 & 16.0 & 5.0 & 66.8 & 9.6 & & & & \\
\hline \multirow[t]{2}{*}{ T. africanus } & TLF-1 & 4.4 & 57.6 & 32.5 & 2.7 & & & & & \\
\hline & TLF-2 & 2.5 & 61.8 & 8.1 & 25.4 & 2.2 & & & & \\
\hline \multirow[t]{2}{*}{ T. melanesiensis } & TLF-1 & 5.5 & 62.1 & 30.8 & 1.6 & & & & & \\
\hline & TLF-2 & 5.6 & 84.7 & 7.1 & 2.6 & & & & & \\
\hline \multirow{2}{*}{$\begin{array}{l}\text { Fervidobacterium. } \\
\text { pennivorans }\end{array}$} & TLF-1 & 1.0 & 54.1 & 9.5 & 35.1 & 0.3 & & & & \\
\hline & TLF-2 & 0.2 & 13.5 & 3.0 & 82.3 & 1.0 & & & & \\
\hline
\end{tabular}

acid (1) and 15,16-dimethyl-30-glyceryloxytriacontanoic acid (5) are abundant lipids in the TLF-1 of T. maritima, it seems likely that the alkyl chains in this GDGT are the same, resulting in structure 11a. At the flank of peak 11a, at slightly higher retention time, a similar mass spectrum was observed with all ions shifted by $28 \mathrm{Da}$ to lower $\mathrm{m} / \mathrm{z}$ values. This compound is likely a GDGT with a $\mathrm{C}_{32}$ and $\mathrm{C}_{30}$ dimethyl alkyl chains (12a), consistent with the presence of small amounts of 13,14-dimethyloctacosanedioic acid (2) and 13,14-dimethyl-28-glyceryloxyoctadecanoic acid (6) in the TLF-1 (Table 2).

The first larger peak in the base peak chromatogram at a retention time of $33.0 \mathrm{~min}$ (labelled 11b or 11c in Fig. 5c) shows an APCI mass spectrum (Fig. 6b) in which all ions are shifted by $14 \mathrm{Da}$ to higher $\mathrm{m} / \mathrm{z}$ values relative to those in the mass spectrum of GDGT 11a (Fig. 6a). In addition, the $[\mathrm{M}+\mathrm{H}]^{+}-18$ peak is substantially increased relative to the $[\mathrm{M}+\mathrm{H}]^{+}$peak and an $[\mathrm{M}+\mathrm{H}]^{+}-74$ peak is also observed. Since this peak disappears when the fraction is subjected to alkaline hydrolysis, this component is likely to contain an ester moiety. This information, together with its molecular mass, indicates that this component is structurally related to GDGT 11a but with one of the ether bonds replaced by an ester bond: a glycerol dialkyl glycerol triether/monoester with two $\mathrm{C}_{32}$ dimethyl alkyl chains (11b), resulting in a molecular mass of $1091\left(\mathrm{C}_{70} \mathrm{H}_{138} \mathrm{O}_{7}\right)$. The presence of the ester moiety likely results in the enhanced $[\mathrm{M}+\mathrm{H}]^{+}-18$ peak in its APCI mass spectrum. Mass chromatography of $\mathrm{m} / \mathrm{z} 1,074$ (Fig. 5c), the abundant $[\mathrm{M}+\mathrm{H}]^{+}-18$ peak, reveals that there is an additional, much later eluting isomer with an identical mass spectrum. This could relate to the position of the ester moiety in this type of components: with the parallel configuration of the glycerol groups, as indicated in 11, there are two possible isomers (11b and 11c). However, it is at present unclear why these positional isomers would differ to a large degree in polarity (i.e. the second isomer elutes much later and is, thus, much more polar than the first one). At the flank of the peak of the triether/monoester a component elutes with a mass spectrum similar to that of $\mathbf{1 1 b}$ but with all the major ions shifted by $28 \mathrm{Da}$ to lower $\mathrm{m} / \mathrm{z}$ values. This component is the triether/monoester with $\mathrm{C}_{32}$ and $\mathrm{C}_{30}$ dimethyl alkyl chains (12b). Mass chromatography of m/z 1,046 (Fig. 5d), the abundant $[\mathrm{M}+\mathrm{H}]^{+}-18$ peak of this component, reveals a second, much later eluting isomer for this component as well.

The most abundant peak in the base peak ion chromatogram at a retention time of $37.0 \mathrm{~min}$ (Fig. 5a) shows a mass spectrum similar to that of the triether/monoester 11b but in which again all major ions are shifted by $14 \mathrm{Da}$ to higher 

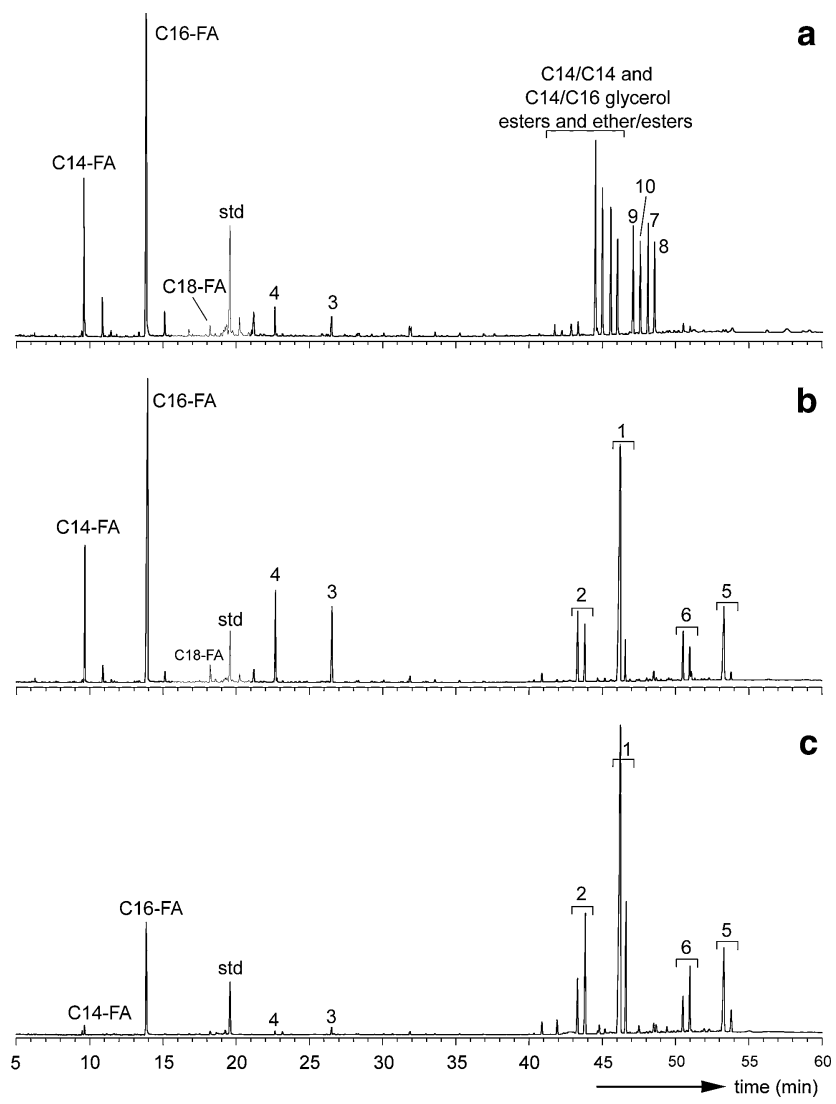

Fig. 4 Gas chromatograms of the total lipid fraction (TLF-1) (a), this fraction after alkaline hydrolysis (TLF-1-OH) (b) and this fraction obtained after alkaline hydrolysis of the residue after extraction (TLF-2) (c) of Thermotoga lettingae ( 2 nd batch). Fatty acids and alcohols were derivatized to the corresponding methyl esters and trimethylsilyl ethers prior to gas chromatographic analysis. Numbers refer to structures indicated in Fig. 2. FA Fatty acid, std internal standard

$\mathrm{m} / \mathrm{z}$ values (cf. Fig. $6 \mathrm{~b}$ and c). This component likely represents a glycerol dialkyl glycerol diether/diester with two $\mathrm{C}_{32}$ dimethyl alkyl chains (11d), resulting in a molecular mass of $\mathrm{m} / \mathrm{z} 1,105\left(\mathrm{C}_{70} \mathrm{H}_{136} \mathrm{O}_{8}\right)$ and an $[\mathrm{M}+\mathrm{H}]^{+}-18$ of $\mathrm{m} / \mathrm{z}$ 1,088. This component is composed of two esterified 15,16-dimethyl-30-glyceryloxytriacontanoic acid (5) units. Moreover, mass chromatography of $\mathrm{m} / \mathrm{z} 1,060$ (Fig. 5f) reveals the presence of a diester/diether with $\mathrm{C}_{32}$ and $\mathrm{C}_{30}$ building blocks (12d). Both the mass chromatograms of $\mathrm{m} / \mathrm{z} 1,088$ (Fig. 5e) and $\mathrm{m} / \mathrm{z} 1,060$ (Fig. 5f) reveal the presence of a much later eluting isomer with similar mass spectra. This latter cluster of peaks contains co-eluting components with a mass spectrum with peaks at $\mathrm{m} / \mathrm{z} 1,120$, $1,106,1,046$ and 1,028, presumably the corresponding glycerol dialkyl glycerol monoether/triester with two $\mathrm{C}_{32}$ dimethyl alkyl chains (11e). Mass chromatograms of $\mathrm{m} / \mathrm{z}$ 1,074 (Fig. 5h) and m/z 1,102 (Fig. 5g) show the presence of a monoether/triester with two $\mathrm{C}_{32}$ dimethyl alkyl moieties (11e) and $\mathrm{C}_{32}$ and $\mathrm{C}_{30}$ building blocks (12e) and much later eluting isomers for both components. These isomers
Table 3 Absolute concentrations (in $\mathrm{mg} \mathrm{g}^{-1}$ dry weight) of diabolic acids and glycerol monoether acids in different species of the order Thermotogales

\begin{tabular}{|c|c|c|c|c|c|}
\hline \multirow[t]{2}{*}{ Bacterial species } & \multirow[t]{2}{*}{ Fraction $^{\mathrm{a}}$} & \multicolumn{4}{|c|}{ Lipids $^{\text {b }}$} \\
\hline & & 1 & 2 & 5 & 6 \\
\hline \multirow{2}{*}{$\begin{array}{l}\text { Thermotoga } \\
\quad \text { maritima }\left(55^{\circ} \mathrm{C}\right)\end{array}$} & TLF-1 & 5.6 & 0.51 & 2.7 & 0.50 \\
\hline & TLF-2 & 4.1 & 0.40 & 2.0 & 0.52 \\
\hline \multirow{3}{*}{$\begin{array}{l}\text { T. lettingae } \\
\text { (2nd batch) }\end{array}$} & TLF-1 & & & & \\
\hline & TLF-1-OH & 7.1 & 1.9 & 1.8 & 1.2 \\
\hline & TLF-2 & 1.9 & 0.46 & 0.38 & 0.25 \\
\hline \multirow[t]{2}{*}{ T. hypogea } & TLF-1 & 1.0 & 0.17 & 0.60 & 0.22 \\
\hline & TLF-2 & 0.70 & 0.02 & 0.49 & 0.16 \\
\hline \multirow[t]{2}{*}{ Thermosipho sp. } & TLF-1 & 0.05 & & & \\
\hline & TLF-2 & 0.26 & 0.04 & & \\
\hline \multirow[t]{2}{*}{ T. africanus } & TLF-1 & 0.01 & & & \\
\hline & TLF-2 & 0.18 & 0.02 & & \\
\hline \multirow[t]{2}{*}{ T. melanesiensis } & TLF-1 & & & & \\
\hline & TLF-2 & 0.01 & & & \\
\hline \multirow{2}{*}{$\begin{array}{l}\text { Fervidobacterium } \\
\text { pennivorans }\end{array}$} & TLF-1 & 7.9 & 0.07 & & \\
\hline & TLF-2 & 3.5 & 0.04 & & \\
\hline
\end{tabular}

${ }^{\text {a }} T L F-1$ Total lipid fraction, $T L F-2$ total lipid fraction obtained after alkaline hydrolysis of the residue after extraction, $T L F-1-O H$ total lipid fraction after base hydrolysis of the extract

${ }^{\mathrm{b}}$ Numbers refer to Fig. 2. Blank entries indicate that the lipid was not detected

possess identical mass spectra (e.g. Fig. 6d). Finally, small amounts of tetraesters with two $\mathrm{C}_{32}$ dimethyl alkyl moieties (11f) and a $\mathrm{C}_{32}$ and a $\mathrm{C}_{30}$ dimethyl alkyl moiety were detected by mass chromatography of $\mathrm{m} / \mathrm{z} 1,116$ (Fig. 5i) and $\mathrm{m} / \mathrm{z}$ 1,088 (Fig. 5j), respectively. A typical mass spectrum is shown in Fig. 6e. In these traces three distinct isomers were observed.

The distribution of membrane-spanning lipids in $T$. maritima is not depending on the growth temperature; cells grown at 80 and $55^{\circ} \mathrm{C}$ showed almost the same distribution.

Distribution of membrane-spanning core lipids in T. lettingae

The distribution of the membrane-spanning lipids in $T$. lettingae was quite different (Fig. 7) from that observed in T. maritima: it was dominated by the diether/diesters with the components with two $\mathrm{C}_{32}$ building blocks $(\mathbf{1 1 d} ; \mathrm{m} / \mathrm{z}$ 1,088; Fig. 7b) and those with a $\mathrm{C}_{32}$ and a $\mathrm{C}_{30}$ dimethyl alkyl chain $(\mathbf{1 2 d} ; \mathrm{m} / \mathrm{z}$ 1,060; Fig. 7c) in approximately equal abundance. Diether/diesters with two $\mathrm{C}_{30}$ building blocks are present in relatively small amounts as revealed by the $\mathrm{m} / \mathrm{z}$ 1,032 mass chromatogram (Fig. 7d). This is consistent with the substantially higher abundance of the $\mathrm{C}_{30}$ diabolic acid (2) relative to the $\mathrm{C}_{32}$ diabolic acid (1) 


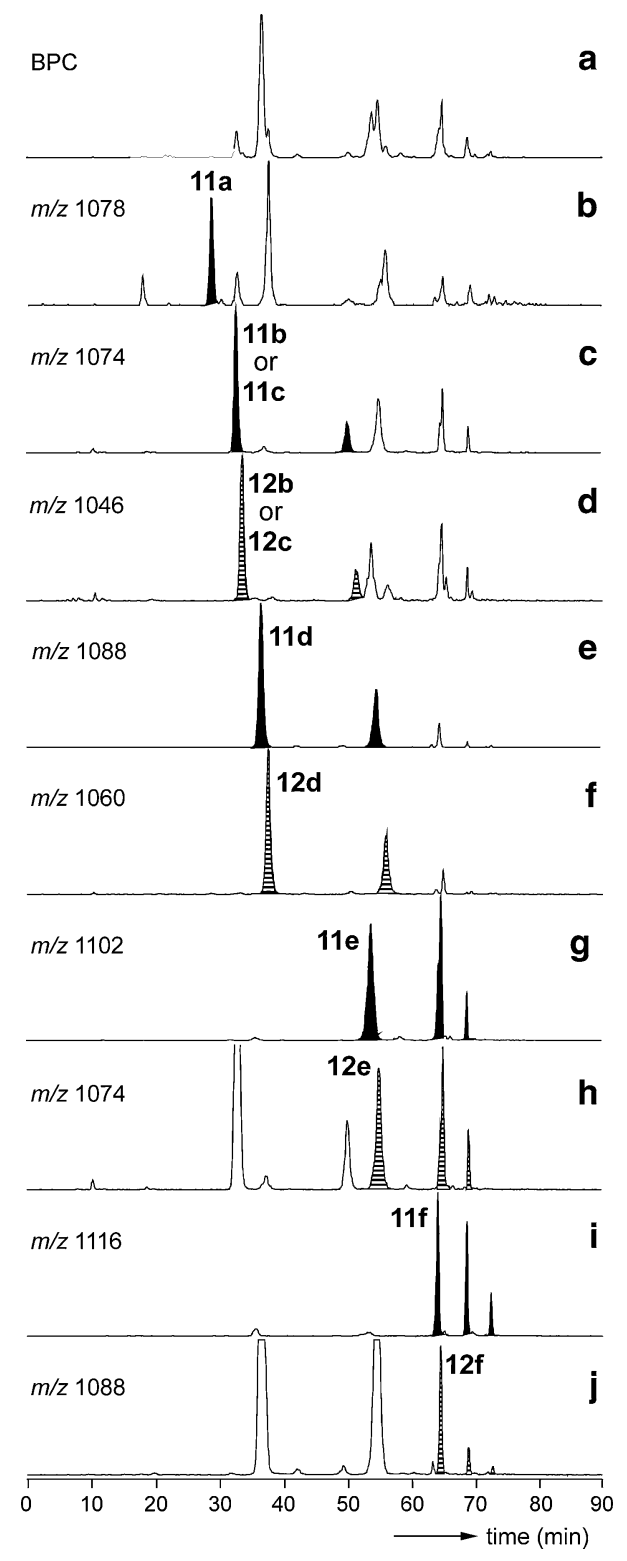

Fig. 5 HPLC/APCI-MS base peak chromatogram (a) and specific mass chromatograms (b-i) of polar lipids of Thermotoga maritima grown at $55^{\circ} \mathrm{C}$. The mass chromatograms, indicative for specific components, are $\mathrm{m} / \mathrm{z} 1,078\left(\mathbf{b}[\mathrm{M}+\mathrm{H}]^{+} \mathrm{C}_{70}\right.$ tetraether $), \mathrm{m} / \mathrm{z} 1,074$ $\left(\mathbf{c}[\mathrm{M}+\mathrm{H}]^{+}-18 \mathrm{C}_{70}\right.$ triether/monoester), $\mathrm{m} / \mathrm{z} 1,046\left(\mathbf{d}[\mathrm{M}+\mathrm{H}]^{+}-18 \mathrm{C}_{68}\right.$ triether/monoester $), \mathrm{m} / \mathrm{z} 1,088\left(\mathbf{e}[\mathrm{M}+\mathrm{H}]^{+}-18 \mathrm{C}_{70}\right.$ diether/diester $)$, $\mathrm{m} / \mathrm{z} 1,060\left(\mathbf{f}[\mathrm{M}+\mathrm{H}]^{+}-18 \mathrm{C}_{68}\right.$ diether/diester $), \mathrm{m} / \mathrm{z} 1,102\left(\mathbf{g}[\mathrm{M}+\mathrm{H}]^{+}-18\right.$ $\mathrm{C}_{70}$ monoether/triester), m/z 1,074 (h $[\mathrm{M}+\mathrm{H}]^{+}-18 \mathrm{C}_{68}$ monoether/triester), $\mathrm{m} / \mathrm{z} \mathrm{1,116}\left(\mathbf{i}[\mathrm{M}+\mathrm{H}]^{+}-18 \mathrm{C}_{70}\right.$ tetraester $), \mathrm{m} / \mathrm{z} 1,088\left(\mathbf{j}[\mathrm{M}+\mathrm{H}]^{+}\right.$$18 \mathrm{C}_{68}$ tetraester). Filled and blocked peaks indicate membrane-spanning lipids based on $\mathrm{C}_{32} / \mathrm{C}_{32}$ and on $\mathrm{C}_{32} / \mathrm{C}_{30}$ branched alkyl chains, respectively. Note that some mass chromatograms are shown twice as they reveal the presence of different components

and the $\mathrm{C}_{33}$ glycerol monoether 6 relative to the $\mathrm{C}_{35}$ glycerol monoether 5 in the TLF-2 fraction of T. lettingae when compared to T. maritima (Table 2). The relatively high abundance of lipids with a $\mathrm{C}_{32}$ and a $\mathrm{C}_{30}$ dimethyl and, to a lesser extent, with two $\mathrm{C}_{30}$ dimethyl alkyl chains is also observed for the monoether/triesters (Fig. 7e-g) and tetraesters (Figs. $7 \mathrm{~h}-\mathrm{j}$ ). Tetraethers (e.g. 11a), which were present in small quantities in T. maritima, were not encountered in T. lettingae.

An additional cluster of early eluting peaks not observed in the HPLC/MS analysis of the extract of $T$. maritima is present in the base peak chromatogram of the polar fraction of T. lettingae (Fig. 8a). The mass spectra of the peaks comprising this cluster are characterized by one dominant fragment ion which is $2 \mathrm{Da}$ higher than that of the $[\mathrm{M}+\mathrm{H}]^{+}-18$ peak of the diether/diesters (cf. Fig. 6f, c). Mass chromatography of $\mathrm{m} / \mathrm{z} 1,090,1,062$ and 1,034 (Fig. 8b-d) reveals that this cluster of peaks is build up in a similar way as the clusters reflecting the diether/diesters, ether/triesters and tetraesters (cf. Fig. 7). These mass chromatograms also reveal that these compounds are accompanied by a later eluting isomer which possess similar mass spectra. These components likely represent glycerol trialkyl glycerol diether/diesters (13d) comprising one longchain $\mathrm{C}_{32}$ or a $\mathrm{C}_{30}$ dimethyl alkyl chain and two shorter linear (predominantly $\mathrm{C}_{16}$ ) alkyl chains. It is well known from archaeal GDGT analyses that so-called "open" or acyclic (in comparison to the macrocyclic components described so far) GDGTs elute substantially earlier under these LC conditions (and are, thus, less polar) and possess APCI mass spectra that do not show an $[\mathrm{M}+\mathrm{H}]^{+}-74$ ion resulting from the loss of a glycerol moiety (Hopmans et al. 2000). Instead, they easily loose one of the shorter alkyl chains upon APCI. Indeed, when the polar fraction of T. lettingae was analysed using an extended mass range $(\mathrm{m} / \mathrm{z}$ 100-1,400), an abundant ion at $\mathrm{m} / \mathrm{z} 792$ was observed, which is likely formed by loss of a $\mathrm{C}_{16}$ moiety. Mass chromatography of ions $2 \mathrm{Da}$ higher than used to detect the monoether/triesters and tetraesters reveals the presence of acyclic monoether/triesters (Fig. 8e-g) and tetraesters (Fig. 8h-j).

Distribution of membrane-spanning core lipids in $F$. pennivorans

Membrane-spanning lipids were also detected in $F$. pennivorans (data not shown). In this case the distribution was relatively simple: only tetraesters with predominantly two $\mathrm{C}_{32}$ dimethyl alkyl chains (11f) were detected in a distribution similar to those observed in T. maritima (Fig. 5i) and T. lettingae (Fig. 7h), i.e. dominated by three isomers. Smaller amounts of tetraesters with a $\mathrm{C}_{32}$ and a $\mathrm{C}_{34}$ dimethyl alkyl chain were also detected. In addition, the TLF-1 also contained a glycerol esterified with two 15,16-dimethyltriacontanedioic acid moieties or 15,16-dimethyltriacontanedioic acid and 15,16-dimethyldotriacontanedioic acid. 
Fig. 6 Partial APCI mass spectra (corrected for background) of (a) the $\mathrm{C}_{70}$ tetraether 11a, (b) the $\mathrm{C}_{70}$ triether/monoester $\mathbf{1 1 b}$ or

11c, (c) the $\mathrm{C}_{70}$ diether/diester

11d, (d) the $\mathrm{C}_{70}$ ether/triester

11e, (e) the $\mathrm{C}_{70}$ diester 11f, (f) the $\mathrm{C}_{70}$ diether/diester 13d
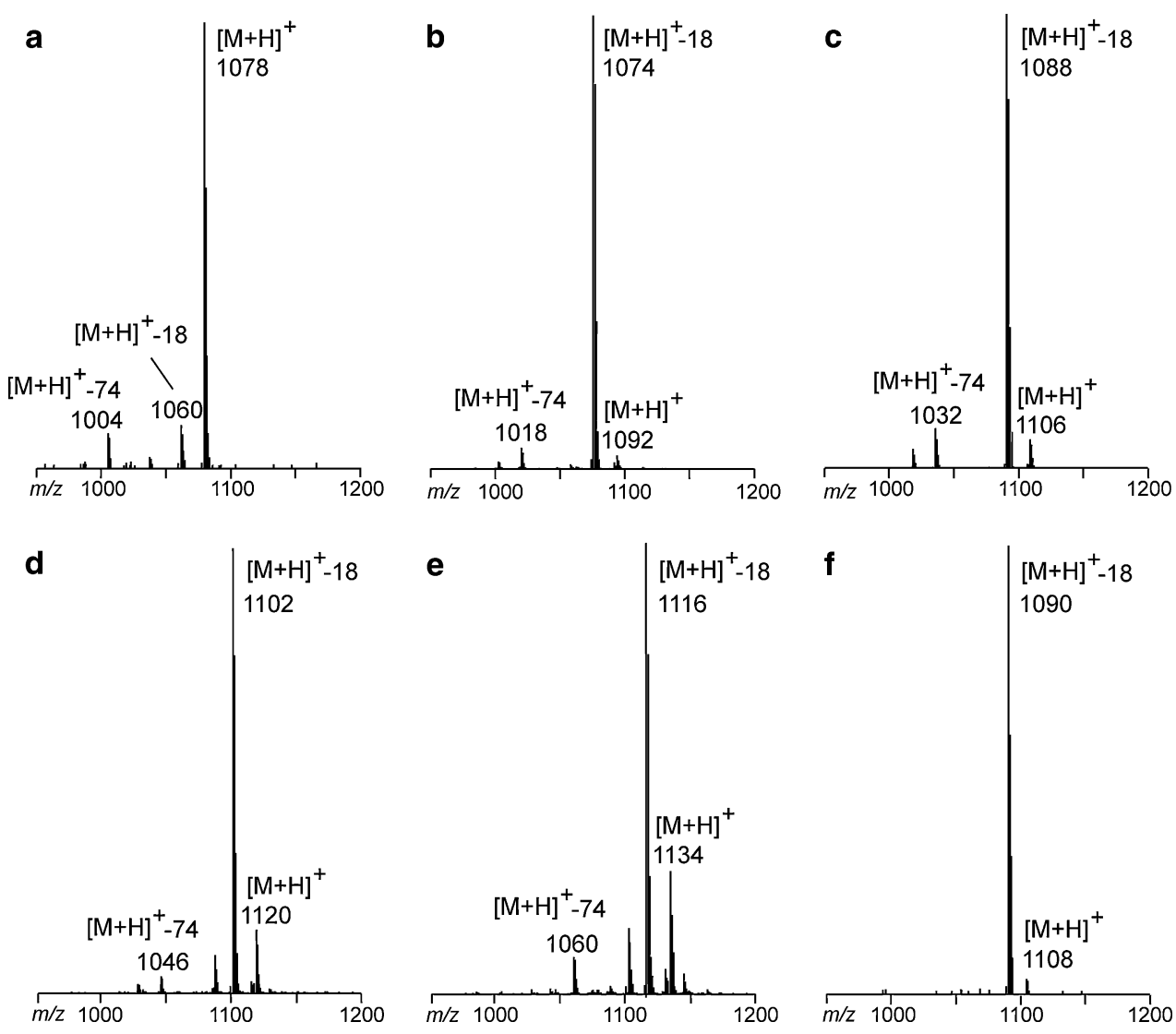

\section{Discussion}

Our results indicate that the diabolic acids and their ether derivatives previously identified in members of the Thermotogales (DeRosa et al. 1988; Windberger et al. 1989; Jeanthon et al. 1995; Huber et al. 1986) are synthesized to produce membrane-spanning lipids and probably represent biosynthetic intermediates. The relative concentration of the diabolic acids and their ether derivatives is substantially higher in the extract obtained after alkaline hydrolysis of the extracted cell residue (TLF-2) (Table 2). The HPLC/ APCI-MS results clearly revealed the presence and, in some cases, the structural complexity of the membranespanning core lipids in species of the order Thermotogales for the first time. Previous investigators (Clarke et al. 1980) have suggested that diabolic acids may act as linkers between two glycerol moieties in polar membrane lipids of Butyrivibrio spp. It is generally thought that the production of membrane-spanning lipids in prokaryotes is an adaptation to high growth temperature, although Butyrivibrio is a mesophile. The ubiquitous presence of diabolic acid-based membrane-spanning lipids in members of the Thermotogales, which are all (hyper)thermophiles, is in line with this general idea (Table 2). However, the distribution of membrane-spanning lipids in T. maritima is not directly affected by the temperature of growth: at both 80 and $55^{\circ} \mathrm{C}$ diabolic acid-based membrane-spanning lipids were produced.

Despite the overall similarity in the lipid composition, there is a clear dichotomy: all members of the genus Thermotoga produce ether lipids (i.e. 3-6, 9-11e, 12a-12e, 13a-13e) in addition to ester lipids, whereas ether lipids are absent in the genera Thermosipho and Fervidobacterium (Table 2). For example, the HPLC/APCI-MS results showed only the presence of tetraesters in $F$. pennivorans, whereas the Thermotoga species investigated showed a wide variety of mixed ester/ether membrane spanning core lipids (Figs. 5, 7, 8). This suggests that only Thermotoga species possess enzymes to produce ether linkages. This classification based on lipid biochemistry is in good agreement with the phylogenetic classification based on the sequence of the 16S rRNA gene (Fig. 9), which reveals that the genera Thermosipho and Fervidobacterium are quite distinct from the genus Thermotoga, although the phylogenetic diversity within the Thermotoga cluster is also substantial.

The composition of the low-molecular-weight lipids (i.e. fatty acids, glycerol monoethers 3 and $\mathbf{4}$ ), higher molecularweight lipids (1-2, 5-6) and the membrane-spanning lipids suggest a biosynthetic relationship between these different lipid classes although the relatively high concentrations of 


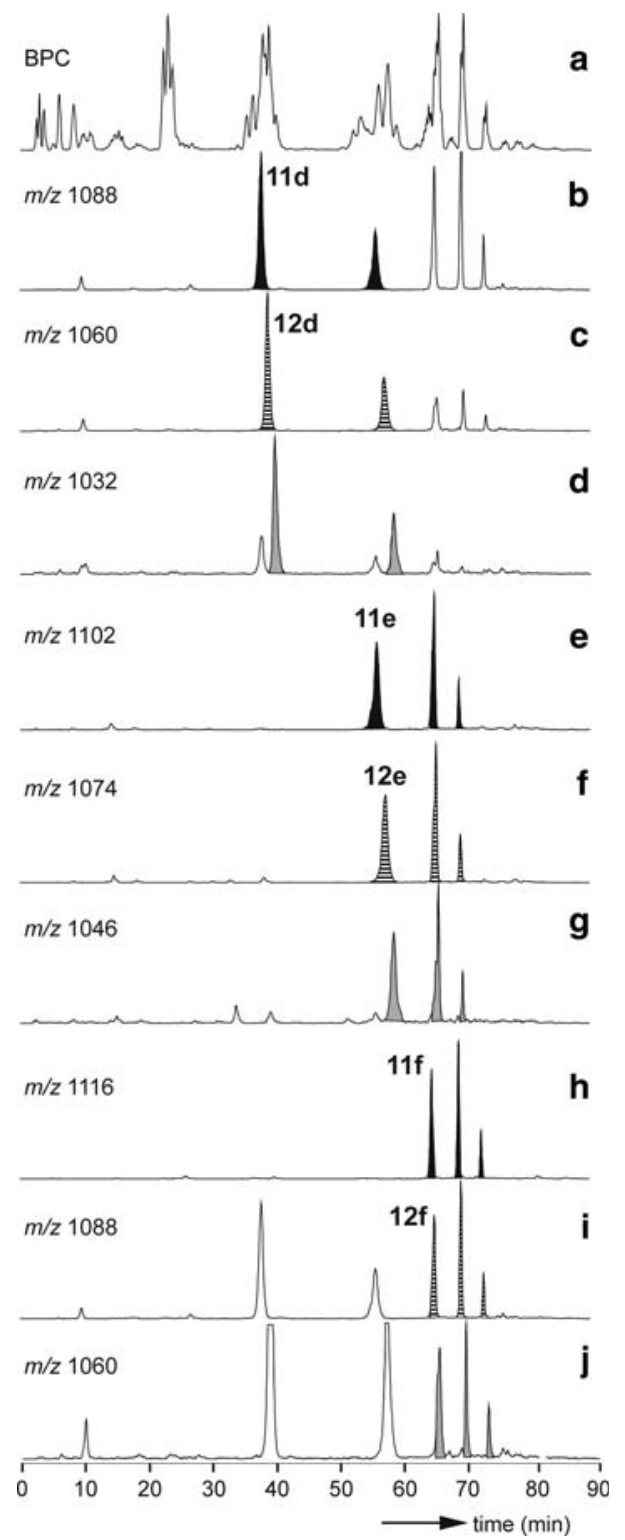

Fig. 7 HPLC/APCI-MS base peak chromatogram (a) and specific mass chromatograms (b-j) of polar lipids of Thermotoga lettingae. The mass chromatograms, indicative for specific components, are $\mathrm{m} / \mathrm{z}$ $1,088\left(\mathbf{b}[\mathrm{M}+\mathrm{H}]^{+}-18 \mathrm{C}_{70}\right.$ diether/diester $), \mathrm{m} / \mathrm{z} 1,060\left(\mathbf{c}[\mathrm{M}+\mathrm{H}]^{+}-18\right.$ $\mathrm{C}_{68}$ diether/diester), $\mathrm{m} / \mathrm{z} 1,032\left(\mathbf{d ~}[\mathrm{M}+\mathrm{H}]^{+}-18 \mathrm{C}_{66}\right.$ diether/diester $), \mathrm{m} / \mathrm{z}$ $1,102\left(\mathbf{e}[\mathrm{M}+\mathrm{H}]^{+}-18 \mathrm{C}_{70}\right.$ monoether/triester $), \mathrm{m} / \mathrm{z} 1,074\left(\mathbf{f}[\mathrm{M}+\mathrm{H}]^{+}-\right.$ $18 \mathrm{C}_{68}$ monoether/triester), $\mathrm{m} / \mathrm{z} 1,046\left(\mathrm{~g}[\mathrm{M}+\mathrm{H}]^{+}-18 \mathrm{C}_{66}\right.$ monoether/ triester), $\mathrm{m} / \mathrm{z} 1,116\left(\mathbf{h}[\mathrm{M}+\mathrm{H}]^{+}-18 \mathrm{C}_{70}\right.$ tetraester $), \mathrm{m} / \mathrm{z} \quad 1,088$ $\left(\mathbf{i}[\mathrm{M}+\mathrm{H}]^{+}-18 \mathrm{C}_{68}\right.$ tetraester $)$ and $\mathrm{m} / \mathrm{z} 1,060\left(\mathbf{j}[\mathrm{M}+\mathrm{H}]^{+}-18 \mathrm{C}_{66}\right.$ tetraester). Filled, blocked and grey peaks indicate membrane-spanning lipids based on $\mathrm{C}_{32} / \mathrm{C}_{32}, \mathrm{C}_{32} / \mathrm{C}_{30}$ and $\mathrm{C}_{30} / \mathrm{C}_{30}$ branched alkyl chains, respectively. Note that some mass chromatograms are shown twice as they reveal the presence of different components

lipids 1-6 also suggest a direct functional role. It has been demonstrated that diabolic acids are produced from condensation reactions of fatty acids at the $\omega-1$ positions (Fitz and Arigoni 1992). These authors showed by the use of $\left[16-{ }^{2} \mathrm{H}_{3}\right]$ palmitic acid and $\left[14-{ }^{2} \mathrm{H}_{2}\right]$ palmitic acid that unsat-

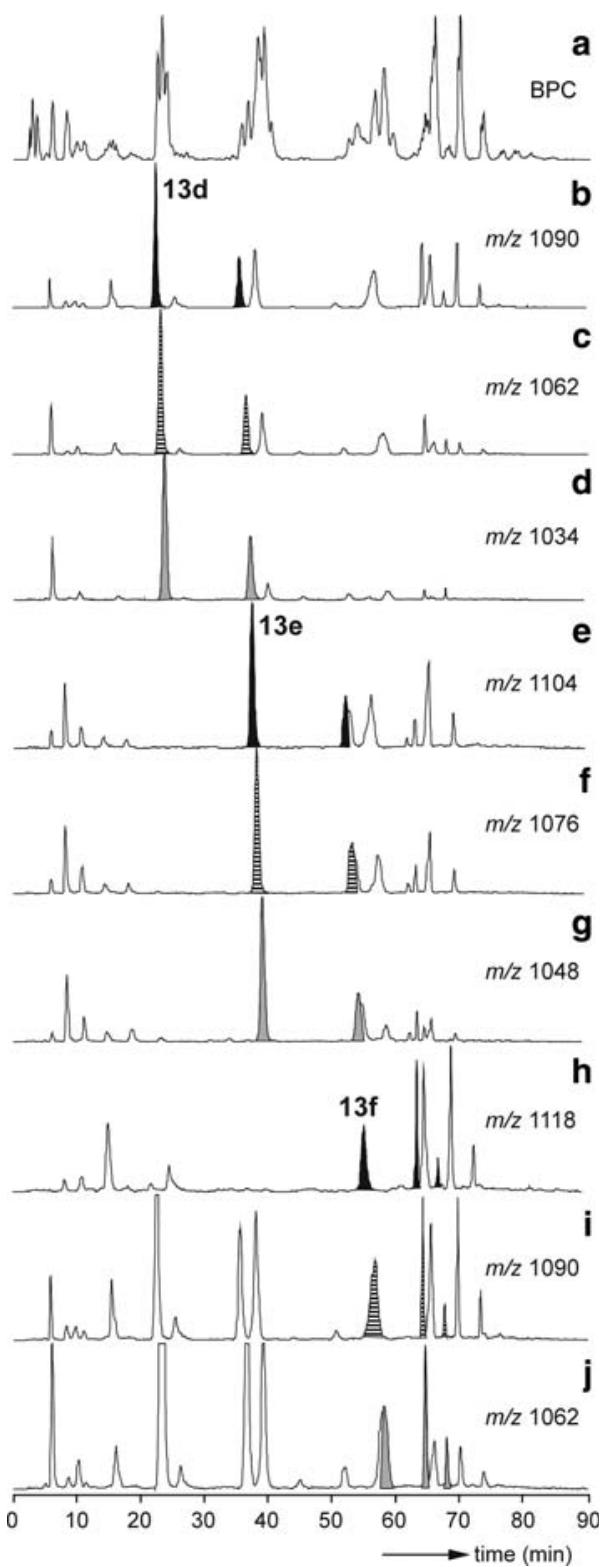

Fig. 8 HPLC/APCI-MS base peak chromatogram (a) and specific mass chromatograms (b-j) of polar lipids of Thermotoga lettingae. The mass chromatograms, indicative for specific components, are $\mathrm{m} / \mathrm{z}$ 1,090 (b $[\mathrm{M}+\mathrm{H}]^{+}-18 \quad \mathrm{C}_{70}$ "open" diether/diester), $\mathrm{m} / \mathrm{z} \quad 1,062$ (c $[\mathrm{M}+\mathrm{H}]^{+}-18 \mathrm{C}_{68}$ "open" diether/diester), $\mathrm{m} / \mathrm{z}$ 1,034 (d [M + H] ${ }^{+}-18$ $\mathrm{C}_{66}$ "open" diether/diester), m/z 1,104 (e [M+H] $]^{+}-18 \mathrm{C}_{70}$ "open" monoether/triester), m/z 1,076 (f $[\mathrm{M}+\mathrm{H}]^{+}-18 \mathrm{C}_{68}$ "open" monoether/ triester $), \mathrm{m} / \mathrm{z} 1,048\left(\mathbf{g}[\mathrm{M}+\mathrm{H}]^{+}-18 \mathrm{C}_{66}\right.$ monoether/triester $), \mathrm{m} / \mathrm{z} 1,118$ (h $[\mathrm{M}+\mathrm{H}]^{+}-18 \mathrm{C}_{70}$ "open" tetraester), m/z 1,090 (i $[\mathrm{M}+\mathrm{H}]^{+}-18 \mathrm{C}_{68}$ "open" tetraester) and $\mathrm{m} / \mathrm{z} 1,062\left(\mathrm{j}[\mathrm{M}+\mathrm{H}]^{+}-18 \mathrm{C}_{66}\right.$ "open" tetraester) for the polar fraction of Thermotoga lettingae. Black, blocked and grey peaks indicate membrane-spanning lipids based on $\mathrm{C}_{32} / \mathrm{C}_{32}, \mathrm{C}_{32} / \mathrm{C}_{30}$ and $\mathrm{C}_{30} / \mathrm{C}_{30}$ branched alkyl chains, respectively. Note that some mass chromatograms are shown twice as they reveal the presence of different components

urated fatty acids are involved in this condensation reaction and that it may be mediated by a free radical reaction. In good agreement with the proposed biosynthetic pathway 


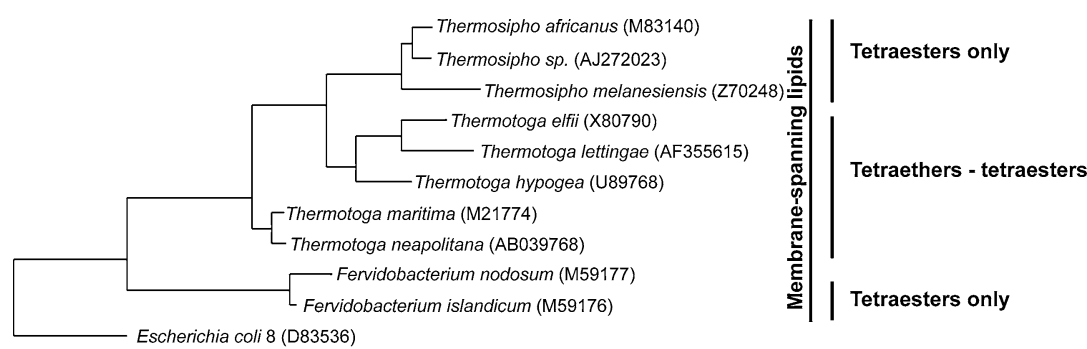

\section{$10 \%$}

Fig. 9 Phylogenetic tree based on the 16S rRNA gene outlining the relationship between molecular phylogeny and lipid composition for the studied species of the Thermotogales. The neighbor-joining tree was reconstructed from distance matrices and Escherichia coli served

for diabolic acids is that in all species investigated in our study the $\mathrm{C}_{16: 0}$ fatty acid is the major fatty acid and 15,16dimethyltriacontanedioic acid (1), composed of two condensed $\mathrm{C}_{16: 0}$ fatty acid moieties, is the major diabolic acid (Table 2). In cases where the $\mathrm{C}_{34}$ and $\mathrm{C}_{30}$ (2) diabolic acids are higher in concentration (e.g. F. pennivorans, and T. lettingae and Thermosipho sp., respectively) also a concomitant increase of the required monomer, i.e. the $\mathrm{C}_{18: 0}$ and $\mathrm{C}_{14: 0}$ fatty acids, respectively, is observed (Table 2). This is also seen in the presumed biosynthetic end-products, i.e. the membrane-spanning core lipids. For example, T. lettingae contains relatively more of these lipids based on $\mathrm{C}_{30}(2)$ diabolic acids, whereas in $F$. pennivorans the $\mathrm{C}_{34}$ diabolic acid is a more important building block. This is consistent with the published observation that during growth of $T$. maritima in batch culture the concentration of the $\mathrm{C}_{16: 0}$ fatty acid decreased with a concomitant increase of tentatively identified diabolic acid (Zhang et al. 2002). This was interpreted to reflect the result of synthesis of diabolic acid using the $\mathrm{C}_{16: 0}$ fatty acid. The same observations can be made for the ether lipids only encountered in the Thermotoga species. The presence of mono alkyl glycerol ethers in all Thermotoga species (Table 2) and mixed glycerol ether/ esters in T. lettingae (2nd batch) (Fig. 4a) suggests that formation of the ether bond may also occur before the condensation reaction, resulting in the synthesis of membranespanning core lipids, takes place. In archaea, GDGTs are also thought to be produced from (partial) condensation of two glycerol diethers (Nishihara et al. 1989; Kon et al. 2002; Koga et al. 1993).

Generally, the distribution of the membrane-spanning lipids is quite complex in the species from the Thermotogales. It is noteworthy that several isomers with a quite different polarity were detected in the HPLC traces. The structural composition of the diacyl glycerols and the mixed glycerol ester/ethers in T. lettingae perhaps provides a clue to the observed complex composition of the membrane-spanning core lipids. Our analyses revealed that the as outgroup. The bar indicates an evolutionary distance of 0.10 . Since no $16 \mathrm{~S}$ rRNA gene sequence is available for $F$. penniforans, two other Fervidobacterium species were used in the construction of the tree. Gene Bank accession numbers are given in parentheses

ester moiety in these lipids can be at both at position 2 and 3 of the glycerol unit when the ether or ester moiety is at position 1 (Fig. 4a). It is quite likely (although this remains to be proven) that this also holds for membrane-spanning core lipids. This introduces a wide variety of structural isomers, which may explain why more than one peak was detected in the various HPLC mass chromatograms (Figs. 5, 6 and 8).

Our data show that some members of the Thermotogales (i.e. the Thermotoga genus) produce membrane-spanning lipids which are comprised of mixed glycerol ether/ester derivatives, whereas all examined species produce membrane-spanning diabolic acids. Mixed glycerol ether/ester lipids have been increasingly recognized in the Bacterial Kingdom, e.g. in Planctomycetes capable of anaerobic ammonium oxidation (Sinninghe Damsté et al. 2002; Sinninghe Damsté et al. 2005), in deep-branching thermophilic bacteria such as Aquifex (Huber et al. 1992) and in two mesophilic sulfate-reducing bacteria (Rütters et al. 2001). The tetraethers 11a and 12a, which occur in low amounts in T. maritima, are, to the best of our knowledge, the first example of this kind of lipid in bacteria. Non-isoprenoidal GDGTs have been detected before in peats (Sinninghe Damsté et al. 2000) but their biological origin is as yet unknown. Membrane spanning lipids are quite common in the Kingdom Archaea (Koga et al. 1993) but have also been identified in a very limited number of bacteria, e.g. in Butyrivibrio spp. (Clarke et al. 1980), and in Thermoanaerobacter species (Jung et al. 1994). It is tempting to associate the peculiar membrane biochemistry of the order Thermotogales to its position in the phylogenetic tree of life, i.e. close to the root of the tree (Woese et al. 1990). The unusually numerous archaeal-like genes (almost 25\%) found in the Thermotoga maritima genome (Nelson et al. 1999) reflect that these are deep-branching bacteria. If species from the order Thermotogales occurred early during the evolution of life on Earth, as suggested by its position in the phylogenetic tree of life, our results indicate that the ability to 
produce both ether and ester glycerol membrane lipids developed relatively early during evolution. All Archaea produce ether membrane lipids, whereas Bacteria and Eukaryotes typically produce glycerol esters. Some members of the Thermotogales, thus, represent a hybrid in this way.

Acknowledgments We thank Drs. M. Elvert and F. Widdel and an anonymous referee for helpful comments.

\section{References}

Antoine E, Cilia V, Meunier JR, Guezennec J, Lesongeur F, Barbier G (1997) Thermosipho melanesiensis sp. nov., a new thermophilic anaerobic bacterium belonging to the order Thermotogales, isolated from deep-sea hydrothermal vents in the Southwestern Pacific Ocean. Int J Syst Bacteriol 47:1118-1123

Balk M, Weijma J, Stams AJM (2002) Thermotoga lettingae sp. nov., a novel thermophilic, methanol-degrading bacterium isolated from a thermophilic anaerobic reactor. Int J Syst Evol Microbiol 52:1361-1368

Carballeira NM, Reyes M, Sostre A, Huang HS, Verhagen MFJM, Adams MWW (1997) Unusual fatty acid compositions of the hyperthermophilic archaeon Pyrococcus furiosus and the bacterium Thermotoga maritima. J Bacteriol 179:2766-2768

Clarke NG, Hazlewood GP, Dawson RMC (1980) Structure of diabolic acid-containing phospholipids isolated from Butyrivibrio sp. Biochem J 191:561-569

Cox RE, Maxwell JR, Ackman RG, Hooper SN (1972) The isolation of a series of acyclic alcohols from an ancient sediment: approaches to a study of the diagenesis and maturation of phytol. In: von Gaertner HR, Wehner H (eds) Advances in organic geochemistry 1971. Pergamon, Oxford, pp 263-276

DeRosa M, Gambacorta A, Huber R, Lanzotti V, Nicolaus B, Stetter KO, Trincone A (1988c) A new 15,16-dimethyl-30-glyceryloxytriacontanoic acid from lipids of Thermotoga maritima. Chem Commun 1300-1301

Fardeau ML, Ollivier B, Patel BKC, Magot M, Thomas P, Rimbault A, Rocchiccioli F, Garcia JL (1997) Thermotoga hypogea sp. nov., a xylanolytic, thermophilic bacterium from an oil-producing well. Int J Syst Bacteriol 47:1013-1019

Fitz W, Arigoni D (1992) Biosynthesis of 15,16-dimethyltriacontanedioic acid (diabolic acid) from [16-(H-2)3]- and [14-(H-2)2]-palmitic acids. Chem Commun 1533-1534

Friedrich AB, Antranikian G (1996) Keratin degradation by Fervidobacterium pennavorans, a novel thermophilic anaerobic species of the order Thermotogales. Appl Environ Microbiol 62:2875-2882

Hopmans EC, Schouten S, Pancost RD, van der Meer MTJ, Sinninghe Damsté JS (2000) Analysis of intact tetraether lipids in archaeal cell material and sediments by high performance liquid chromatography/atmospheric pressure chemical ionization mass spectrometry. Rapid Commun Mass Spectrom 14:585-589

Huber R, Hannig M (2005) Thermotogales. In: Dworkin M et al (ed) The prokaryotes: an evolving electronic resource for the microbiological community, 3rd edn. Springer, New York, http:// link.springer-ny.com/link/service/books/10125/

Huber R, Langworthy TA, Konig H, Thomm M, Woese CR, Sleytr UB, Stetter KO (1986) Thermotoga maritima sp. nov. represents a new genus of unique extremely thermophilic eubacteria growing up to $90^{\circ} \mathrm{C}$. Arch Microbiol 144:324-333

Huber R, Woese CR, Langworthy TA, Fricke H, Stetter KO (1989) Thermosipho africanus gen. nov. represents a new genus of thermophilic eubacteria within the Thermotogales. Syst Appl Microbiol 12:32-37

Huber R, Wilharm T, Huber D, Trincone A, Burggraf S, König H, Rachel R, Rockinger I, Fricke H, Stetter KO (1992) Aquifex pyrophilus gen. nov. sp. nov., represents a novel group of marine hyperthermophilic hydrogen-oxidizing bacteria. System Appl Microbiol 15:340-351

Jannasch HW, Huber R, Belkin S, Stetter KO (1988) Thermotoga neapolitana sp. nov. of the extremely thermophilic, eubacterial genus Thermotoga. Arch Microbiol 150:103-104

Jeanthon C, Reysenbach A-L, L'Haridon S, Gambacorta A, Pace NR, Glénat P, Prieur D (1995) Thermotoga subterranea sp. nov., a new thermophilic bacterium isolated from a continental oil reservoir. Arch Microbiol 164:91-97

Jung SH, Zeikus JG, Hollingsworth RI (1994) A new family of very long-chain alpha,omega-dicarboxylic acids is a major structural fatty acyl component of the membrane-lipids of Thermoanaerobacter ethanolicus 39e. J Lipid Res 35:1057-1065

Klein RA, Hazlewood GP, Kemp P, Dawson RMC (1979) A new series of long-chain dicarboxylic acids with vicinal dimethyl branching found as major components of the lipids of Butyrivibrio spp. Biochem J 183:691-700

Koch R, Canganella F, Hippe H, Jahnke KD, Antranikian G (1997) Purification and properties of a thermostable pullulanase from a newly isolated thermophilic anaerobic bacterium, Fervidobacterium pennavorans Ven5. Appl Environ Microbiol 63:1088-1094

Koga Y, Nishihara M, Morii H, Akagawa-Matsushita M (1993) Ether polar lipids of methanogenic bacteria: structures, comparative aspects, and biosyntheses. Microbiol Rev 57:164-182

Kon T, Nemoto N, Oshima T, Yamagishi A (2002) Effects of a squalene epoxidase inhibitor, terbinafine, on ether lipid biosyntheses in a thermoacidophilic archaeon, Thermoplasma acidophilum. J Bacteriol 184:1395-1401

Manca MC, Nicolaus B, Lanzotti V, Trincone A, Gambacorta A, Peterkatalinic J, Egge H, Huber R, Stetter KO (1992) Glycolipids from Thermotog a maritima, a hyperthermophilic microorganism belonging to bacteria domain. Biochim Biophys Acta 1124:249-252

Nelson KE, Clayton RA, Gill SR, Gwinn ML, Dodson RJ, Haft DH, Hickey EK, Peterson LD, Nelson WC, Ketchum KA, McDonald L, Utterback TR, Malek JA, Linher KD, Garrett MM, Stewart AM, Cotton MD, Pratt MS, Phillips CA, Richardson D, Heidelberg J, Sutton GG, Fleischmann RD, Eisen JA, White O, Salzberg SL, Smith HO, Venter JC, Fraser CM (1999) Evidence for lateral gene transfer between Archaea and Bacteria from genome sequence of Thermotoga maritima. Nature 399:323-329

Nishihara M, Morii H, Koga Y (1989) Heptads of polar ether lipids of an Archaebacterium, Methanobacterium thermoautotrophicumstructure and biosynthetic relationship. Biochemistry 28:95-102

Ravot G, Magot M, Fardeau ML, Patel BKC, Prensier G, Egan A, Garcia JL, Ollivier B (1995) Thermotoga elfii sp. nov., a novel thermophilic bacterium from an African oil-producing well. Int J Syst Bacteriol 45:308-314

Rütters H, Sass H, Cypionka H, Rullkötter J (2001) Monoalkylether phospholipids in the sulfate-reducing bacteria Desulfosarcina variabilis and Desulforhabdus amnigenus. Arch Microbiol 176:435-442

Sinninghe Damsté JS, Hopmans EC, Pancost RD, Schouten S, Geenevasen JAJ (2000) Newly discovered non-isoprenoid glycerol dialkyl glycerol tetraether lipids in sediments. Chem Commun 16831684

Sinninghe Damsté JS, Rijpstra WIC, Geenevasen JAJ, Strous M, Jetten MSM (2005) Structural identification of ladderane and other membrane lipids of planctomycetes capable of anaerobic ammonium oxidation (anammox). FEBS J 272:4270-4283

Sinninghe Damsté JS, Strous M, Rijpstra WIC, Hopmans EC, Geenevasen JAJ, van Duin ACT, van Niftrik LA, Jetten MSM (2002) 
Linearly concatenated cyclobutane lipids form a dense bacterial membrane. Nature 419:708-712

Windberger E, Huber R, Trincone A, Fricke H, Stetter KO (1989) Thermotoga thermarum sp. nov. and Thermotoga neapolitana occurring in African continental solfataric springs. Arch Microbiol 151:506-512

Woese CR (1987) Bacterial Evolution. Microbiol Rev 51:221-271

Woese CR, Kandler O, Wheels ML (1990) Towards a natural system of organisms: proposal for the domains Archaea, Bacteria, and Eucarya. Proc Natl Acad Sci USA 87:4576-4579
Wood GW (1980) Complex lipids. In: Waller GR, Dermer OC (eds) Biochemicacal applications of mass spectrometry. Wiley, New York pp 173-209

Zhang CL, Ye Q, Reysenbach A-L, Götz D, Peacock A, White DC, Horita J, Cole DR, Fong J, Pratt L, Fang J, Huang Y (2002) Carbon isotopic fractionations associated with thermophilic bacteria Thermotoga maritima and Persephonella marina. Environ Microbiol 4:58-64 